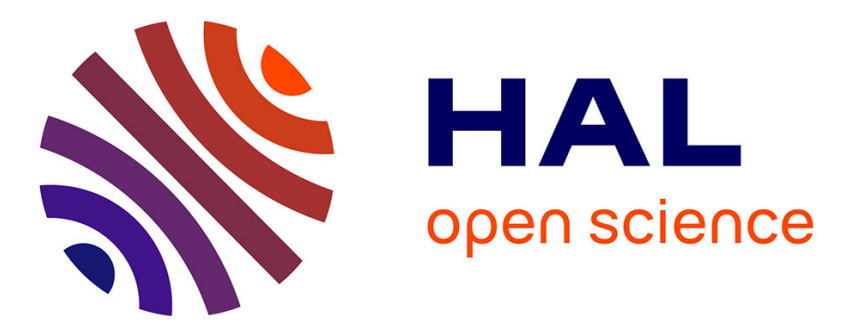

\title{
Gold-Catalyzed Spirocyclization Reactions of N-Propargyl Tryptamines and Tryptophans in Aqueous Media
}

Nazarii Sabat, Feryel Soualmia, Pascal Retailleau, Alhosna Benjdia, Olivier Berteau, Xavier Guinchard

\section{To cite this version:}

Nazarii Sabat, Feryel Soualmia, Pascal Retailleau, Alhosna Benjdia, Olivier Berteau, et al.. GoldCatalyzed Spirocyclization Reactions of N-Propargyl Tryptamines and Tryptophans in Aqueous Media. Organic Letters, 2020, 22 (11), pp.4344-4349. 10.1021/acs.orglett.0c01370 . hal-03004181

\section{HAL Id: hal-03004181 \\ https://hal.science/hal-03004181}

Submitted on 13 Nov 2020

HAL is a multi-disciplinary open access archive for the deposit and dissemination of scientific research documents, whether they are published or not. The documents may come from teaching and research institutions in France or abroad, or from public or private research centers.
L'archive ouverte pluridisciplinaire HAL, est destinée au dépôt et à la diffusion de documents scientifiques de niveau recherche, publiés ou non, émanant des établissements d'enseignement et de recherche français ou étrangers, des laboratoires publics ou privés. 


\title{
Gold-Catalyzed Spirocyclization Reactions of $\boldsymbol{N}$-Propargyl Tryptamines and Tryptophans in Aqueous Media
}

\author{
Nazarii Sabat, ${ }^{1}$ Feryel Soualmia, ${ }^{2}$ Pascal Retailleau, ${ }^{1}$ Alhosna Benjdia, ${ }^{2}$ Olivier Berteau, ${ }^{2}$ Xavier \\ Guinchard $^{1 *}$
}

${ }^{1}$ Université Paris-Saclay, CNRS, Institut de Chimie des Substances Naturelles, UPR 2301, 91198, Gif-sur-Yvette, France.

E-mail : xavier.guinchard@cnrs.fr

${ }^{2}$ Université Paris-Saclay, INRAE, AgroParisTech, Micalis Institute, ChemSyBio, 78350 Jouy-en-Josas, France.

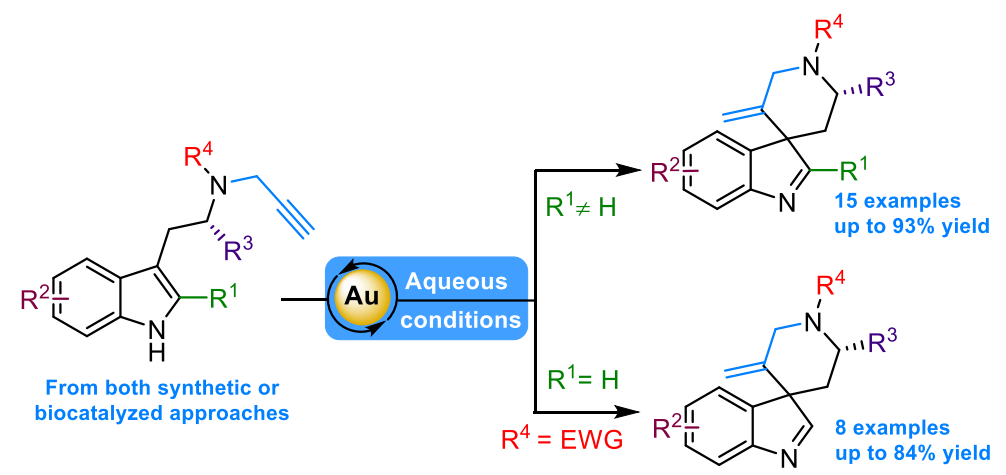

$\mathrm{N}$-Propargyl tryptamine and tryptophan derivatives that are readily available from both synthetic and biocatalytic approaches, undergo gold-catalyzed dearomative cyclizations in aqueous media to the corresponding spirocyclic derivatives. In addition to the efficiency of the method, operating in aqueous media affords a selective entry to C2-unsubstituted spiroindolenines that have long remained unattainable by $\mathrm{Au}(\mathrm{I})$-catalysis. Moderate to excellent yields of the desired spirocyclic products bearing various substituents were obtained.

The $\mathrm{Au}(\mathrm{I})$-catalyzed ${ }^{1}$ spirocyclization of indoles ${ }^{2,3}$ tethered to alkynes is an important reaction since it leads to high-value spiroindole alkaloids. ${ }^{4,5,6}$ The mechanisms associated with this reactivity are, however, somewhat labyrinthic. Activation of the triple bond by the cationic $\mathrm{Au}(\mathrm{l})$ complex initiates the kinetically favored formation of spirocyclic vinylgold intermediate ii. However, this key intermediate then evolves differently depending on the C2-substitution of the indole ring (Scheme 1, eq. 1). (1) C2 substituted compounds undergo protodeauration to the chiral spiroindoles iii (Path A). ${ }^{7}$ (2) Unsubstituted compounds (Path B), lead to the annulated product iv, supposedly as the result of a C3-to-C2 migration from ii. ${ }^{7 a, 8,9}$ (3) A nucleophile can trap the spirocyclic vinylgold intermediate and lead to the reduced spirocyclic compounds $\boldsymbol{v}(\operatorname{Path} \mathrm{C}) .{ }^{10}(4)$ If the protodeauration of the spiro intermediate $\boldsymbol{i} i$ is slow, owing to the potential reversibility of spirocyclization step, then a direct $\mathrm{C} 2$ addition (Path $\mathrm{D}$ ) leading to the thermodynamic product iv is not to be precluded. ${ }^{11}$

In the tryptamine series, Echavarren showed for instance that $N$-propargyl tryptamines $\mathbf{A}$ bearing electron-withdrawing groups ( $R=E W G$ ) lead exclusively to the hexahydroazepino[4,5-b]indole B (Scheme 1, eq. 2), ${ }^{\text {7a }}$ while we reported that spiroindolenines $\mathbf{C}$ can be selectively obtained only if $\mathrm{R}=\mathrm{EDG}$ (Scheme 1, eq. 2 ). ${ }^{11 b, 12}$ 
Recently, You and Zhang triggered cyclizations in the presence of a Hantzsch ester acting as an hydride donor to in situ reduce the iminium intermediate leading to compounds $\mathbf{D}$ (Scheme 1, eq. 2). ${ }^{10 \mathrm{~d}}$ These accomplishments constitute indirect evidence for the intermediacy of the spirocyclic vinylgold species ii. However, still the actual C2-unsubstituted spiroindolenines remain inaccessible, at least with classical electron-withdrawing protecting groups on the nitrogen.

The development of catalytic reactions in aqueous media is a rapidly growing field, not only because of environmental concerns but also of the unique selectivities that water properties may bring to a given reaction. ${ }^{13}$ Considering the robustness of gold catalysts when exposed to moisture and oxygen, water has been used successfully as a (co)solvent in gold catalysis. ${ }^{14}$

We hypothesized that operating in a polar, protic media would fasten the protodeauration step and potentially allow the isolation of the spiroindolenines, even with unsubstituted compounds. In this paper, we report the gold-catalyzed spirocyclizations of tryptamine and tryptophan derivatives $\mathbf{1}$ in aqueous media, delivering a range of spiroindolenines $\mathbf{2}$ (Scheme 1, eq. 3). In particular, we show that the use of water media allows the selective formation and the isolation of the C2-unsubstituted spiroindolenines.

Scheme 1. Selectivities in Gold-Catalyzed Cyclizations of Alkyne-Tethered Indole Derivatives
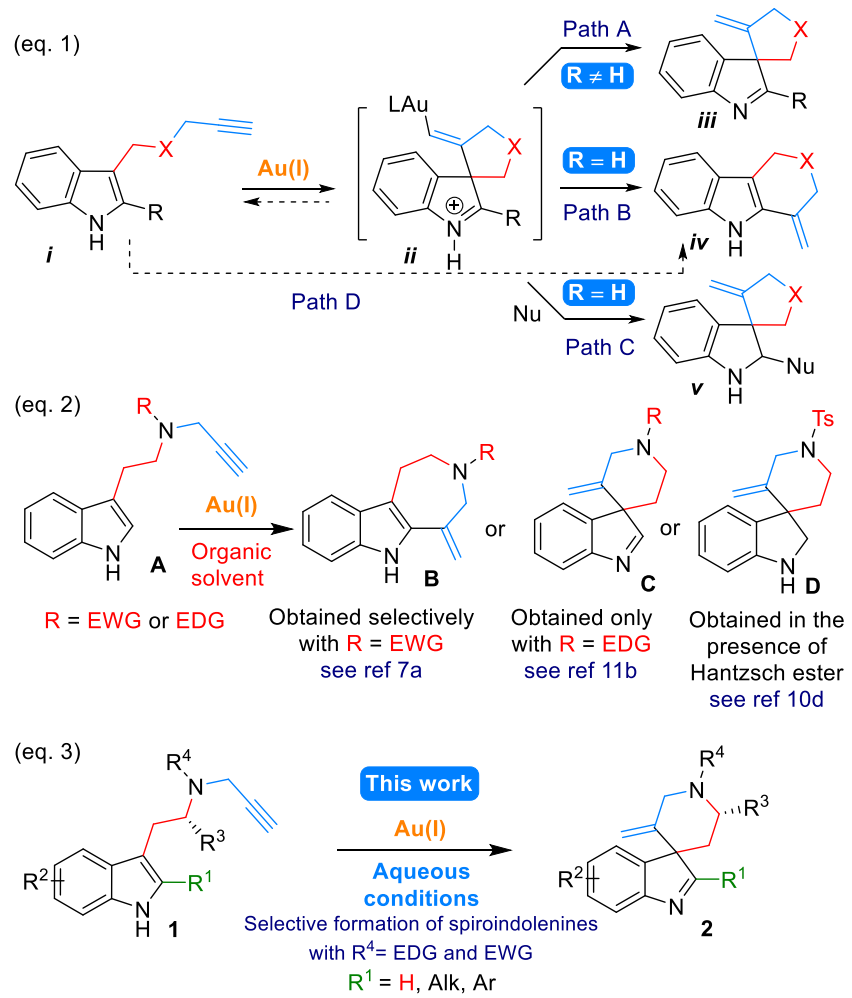

We first sought suitable conditions to promote the spirocyclization of a model 2-methyl- $N$-nosyl- $N$-propargyl tryptamine $1 \mathrm{a}$ in an aqueous environment to ensure the possibility to make this chemistry under aqueous conditions (Table 1, entry 1 2). Screening of micellar conditions using TPGS-750M (DL- $\alpha$-Tocopherol methoxypolyethylene glycol succinate) as the surfac$\operatorname{tant}^{15}$ and the Echavarren catalyst 3a resulted in moderate conversions (entry 1). We then identified that mixtures of MeCN and water yields high conversions of spiroindolenine 2a (entry 2; higher amount of water lead to reduced conversions, see SI for the full optimization table). 
Table 1. Optimization of the Gold-Catalyzed Cyclizations in Aqueous Media

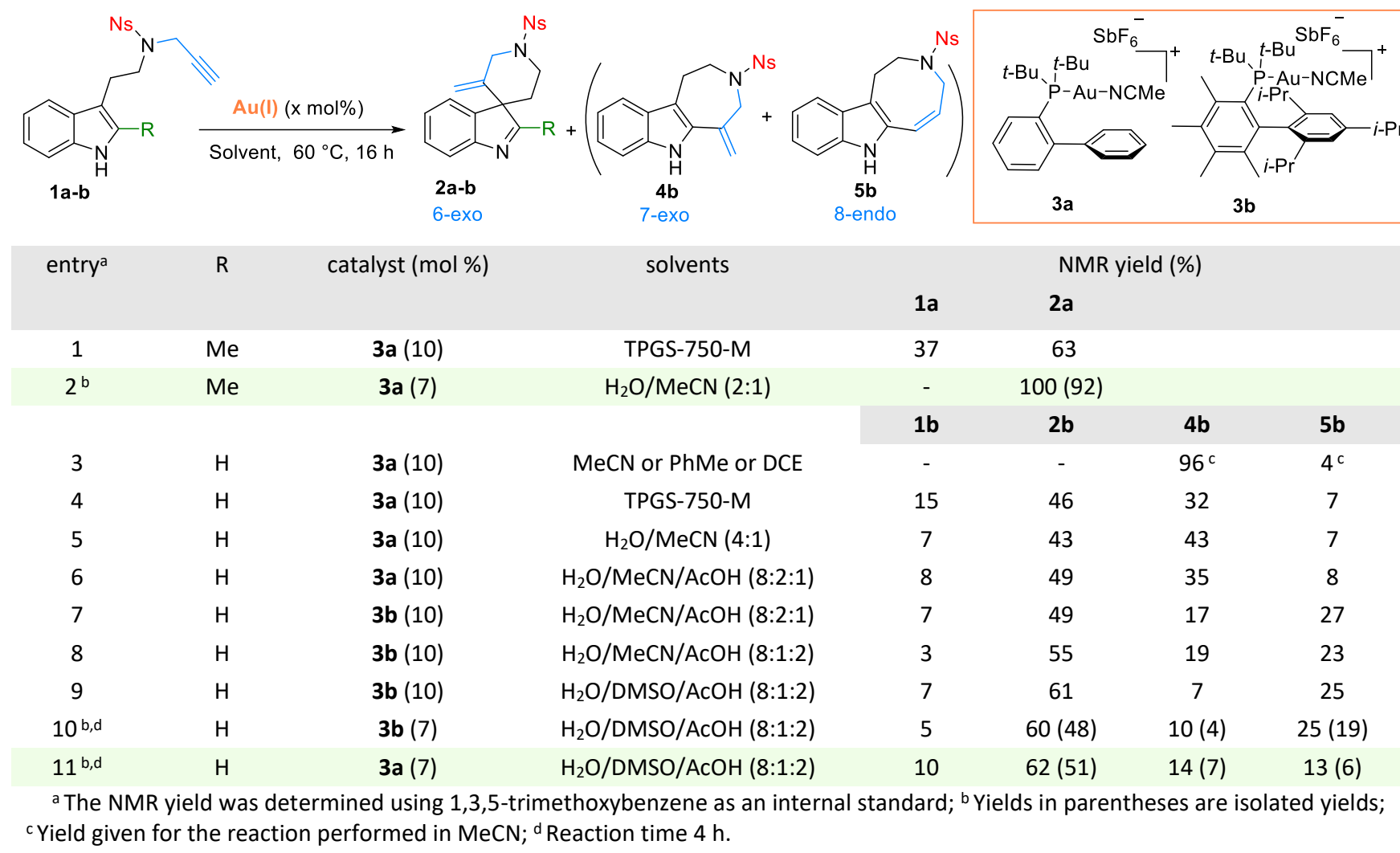

Next, we turned our attention to the more challenging cyclization of C2-unsubstituted tryptamine 1b upon gold-catalyzed conditions in aqueous phase and analyzed the crude mixtures by ${ }^{1} \mathrm{H}$ NMR. This reaction can deliver three distinct products, namely the desired spiroindolenine $\mathbf{2} \mathbf{b}$, the hexahydroazepino[4,5-b]indole $\mathbf{4 b}$ and the tetrahydro-1H-azocino[5,4- $b]$ indole $\mathbf{5 b}$ (potentially resulting from the direct 8-endo addition of the indole), that are easily separable on silica gel. We first verified that the reaction performed in organic solvent leads in all cases to the exclusive high yielding formation of the formal 7-exo addition product $\mathbf{4 b}$, as reported by Echavarren (entry 3 )..$^{7 a}$ When the reaction was performed in micellar conditions at $60{ }^{\circ} \mathrm{C}$, despite partial conversion, the main product appeared to be the spiroindolenine $\mathbf{2} \mathbf{b}$ (entry 4 ). ${ }^{16}$ We next attempted catalyst $\mathbf{3 a}$ in a $4: 1$ mixture of $\mathrm{H}_{2} \mathrm{O} / \mathrm{MeCN}$, leading to $\mathbf{4 b}$ equimolar to $\mathbf{2} \mathbf{b}$ (entry 5 ). With the idea that the addition of an acid would even better facilitate the protodeauration, ${ }^{17}$ we introduced a small proportion of acetic acid to the solvent system that led as expected to a higher amount of desired spirocycle $\mathbf{2 b}$ (entry 6 ). We then found that catalyst $\mathbf{3 b}$ delivered the same $\mathbf{4 9 \%}$ yield of $\mathbf{2} \mathbf{b}$, but resulted in the increase of $\mathbf{8 - m e m b e r e d ~ r i n g ~ p r o d u c t ~} \mathbf{5 b}$ at the expense of $\mathbf{4 b}$ (entry $\mathbf{7}$ ). This is remarkable since product $\mathbf{5 b}$ was known so far to result from cyclizations using only $\mathrm{AuCl}_{3}$ or $\mathrm{AuCl}$ catalysts, but not from catalysts bearing a phosphine ligand. ${ }^{7 a}$ The proportion of $\mathbf{2} \mathbf{b}$ increased with higher amount of acetic acid (entry 8 ) and the switch of the organic co-solvent to DMSO, led to $61 \%$ of desired spiroindolenine $\mathbf{2 b}$ (entry 9 ). A decrease of the reaction time to 4 hours and the catalyst loading to 7 mol\% allowed to isolate the spiroindolenine $\mathbf{2} \mathbf{b}$ in average $50 \%$ yields and high selectivities, using either catalyst $\mathbf{3 a}$ or $\mathbf{3 b}$ (entries 10-11). 
Scheme 2. Scope of the Gold-Catalyzed Spirocyclizations of Tryptamine and Tryptophan Derivatives

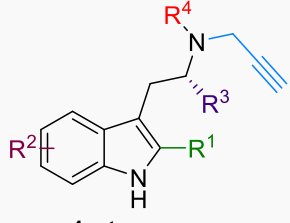

a-t
$3 a(7 \mathrm{~mol} \%)$

A: $\mathrm{H}_{2} \mathrm{O} / \mathrm{MeCN}(2: 1), 60-90{ }^{\circ} \mathrm{C}, 4-72 \mathrm{~h}$

B: $\mathrm{H}_{2} \mathrm{O} / \mathrm{DMSO} / \mathrm{AcOH}(8: 1: 2), 60^{\circ} \mathrm{C}, 4 \mathrm{~h}$

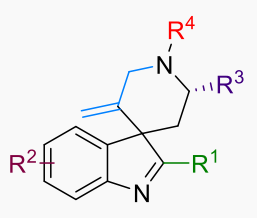

2a-t

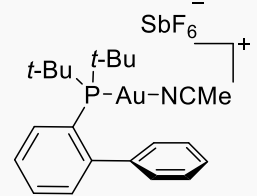

$3 a$

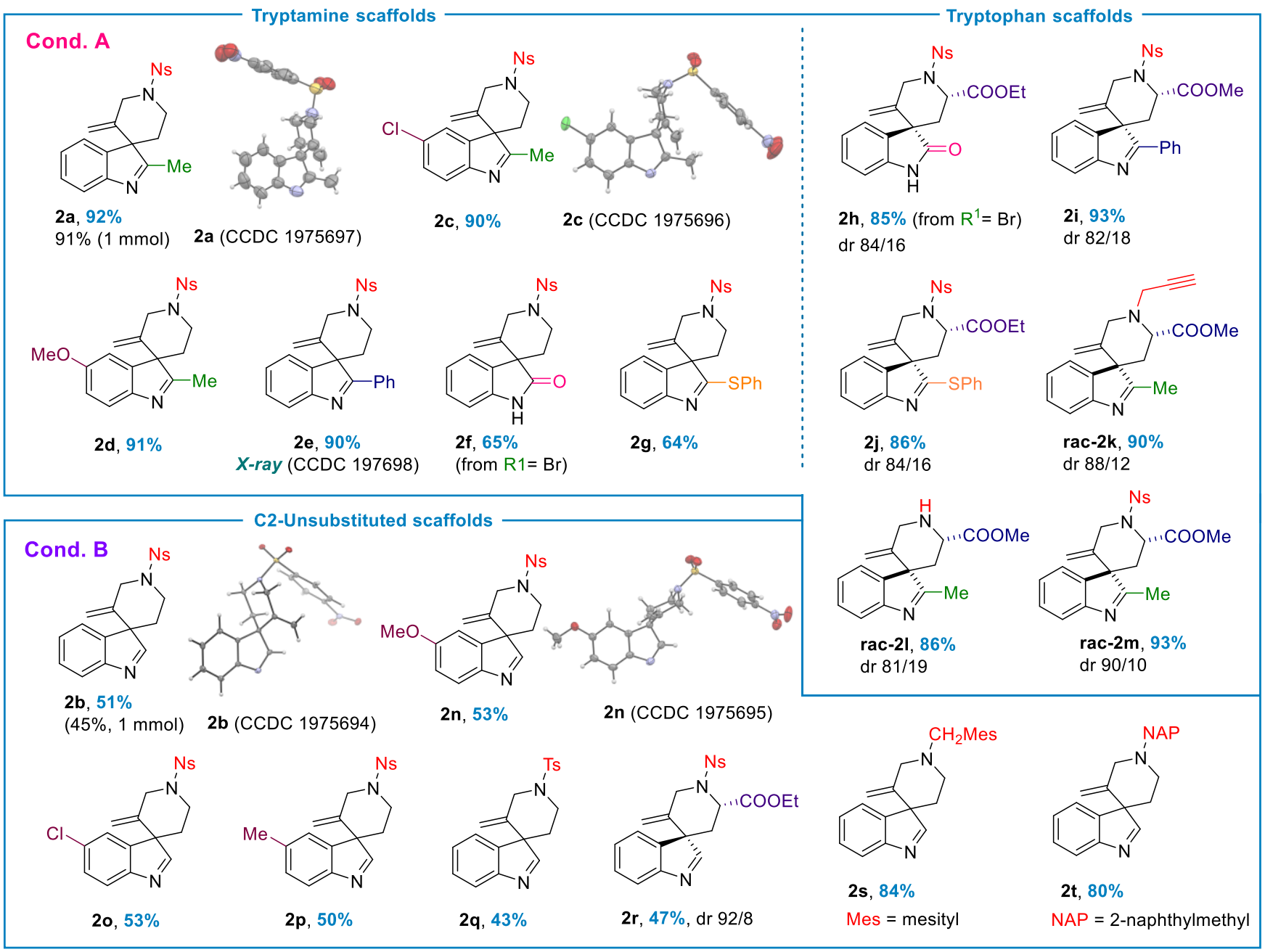

It is clear from these results that water offers interesting opportunities in this complex mechanistic scenario and that concomitant efforts directed at the identification of the gold complex and the solvent system can reverse selectivities obtained toward one or the other compounds of the series. ${ }^{18}$ Interestingly also, we never observed any product resulting from the potential gold-catalyzed hydration of the triple bond under those conditions. ${ }^{19}$

A series of C2-substituted tryptamines 1a-g were then engaged in gold-catalyzed cyclizations, using 7 mol\% of $3 a$ to ensure full conversions within a few hours. (Scheme 2). The reference spiroindolenine 2 a was obtained in $91 \%$ yield on a $1.0 \mathrm{mmol}$ scale. The introduction of chlorine and methoxy substituents at position 5 of the indole had no impact on the reaction, delivering $\mathbf{2 c}$ and $\mathbf{2 d}$ in excellent yields. With a phenyl group at $\mathbf{C 2}$, the reaction proceeded well. When 2-bromotryptamine $\mathbf{1}$ f was used, the spirooxindole $\mathbf{2 f}$ was obtained in $61 \%$ yield, resulting from the in situ hydrolysis of the intermediate 2-bromospiroindolenine. ${ }^{7 c, 20}$ Finally, a thiophenyl moiety was introduced at $\mathrm{C} 2$ and led to the product $\mathbf{2 g}$ in $64 \%$ yield. We next 
switched to tryptophan-derivatives as starting materials ${ }^{21}$ and could isolate spirooxindole $\mathbf{2} \mathbf{h}$ and spiroindolenines $\mathbf{2} \mathbf{i}$ and $\mathbf{2} \mathbf{j}$ in excellent yields and diastereoselectivities. ${ }^{22}$ We next exposed racemic 2-Me tryptophan derivatives $\mathbf{1 k - 1} \mathbf{m}$ to cyclization conditions and obtained the corresponding spiroindolenines rac-2k, rac-2l and rac-2 $\mathbf{m}$ in excellent yields and diastereoselectivities. Notably, the reaction worked well with unprotected amine 1I. We next engaged a series of challenging C2-unsubstituted tryptamines/tryptophans $\mathbf{1 b} \mathbf{1} \mathbf{1} \mathbf{n - t}$ in the established conditions. Product $\mathbf{2} \mathbf{b}$ was obtained in $51 \%$ isolated yield (that decreased to $45 \%$ on a $1.0 \mathrm{mmol}$ scale). Gratifyingly, the compound $\mathbf{2 b}$ crystallized and led to the corresponding X-ray structure. Remarkably, one of our crystallization attempts led to the formation of the crystalline trimer 6 (Figure 1). Despite the fact that this equilibrated trimerization has been known from the 1930 's, ${ }^{23}$ crystal structures of spiroindolenines in a trimeric form have not been reported so far. From our experimental observations, we eventually concluded that compound $\mathbf{2 b}$ undergoes partial trimerization when it goes from solution to solid state, which is why the NMR spectrum of the purified compound does not show absolute purity and isolated yields are typically lower than NMR yields. We could show that the pure compound is easily obtained from purification on silica gel by concentration of the organic phase in the presence of a nonvolatile deuterated solvent (i.e. d6-DMSO) to prevent solidification.

Figure 1. X-ray Structure of Trimer 6

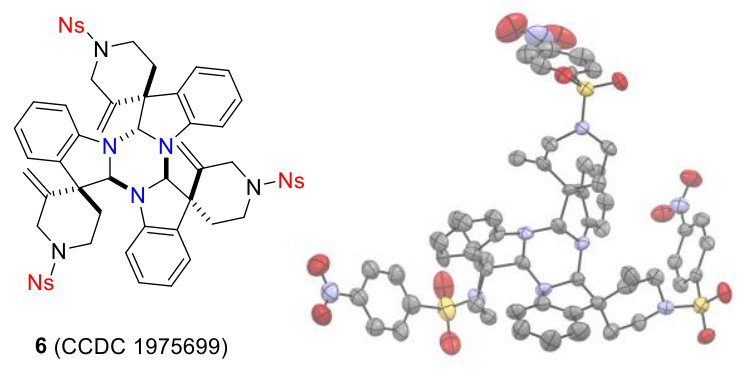

We next engaged 5-methoxy, 5-chloro and 5-methyltryptamines 1n-p in the cyclizations and obtained the spiroindolenines in similar average of $53 \%$ yields. The replacement of the nosyl group by a tosyl dropped the yield of $2 q$ to $43 \%$. The use of a tryptophan-derived starting material led to the spiro compound $2 \mathrm{r}$ in $47 \%$ yield. We next used $N$-propargyl tryptamines 1 s and $\mathbf{1 t}$ to obtain the two spiroindolenines $\mathbf{2 s - t}$ in excellent yields and chemoselectivities. Those tryptamines with their electron-donating groups show a similar level of regioselectivity when operating in an organic solvent. ${ }^{11 b}$

Some of the tryptophan spirocyclic compounds $(\mathbf{2 k - 2 m )}$ were racemic because of synthetic reasons. We sought an alternative approach allowing access to enantiopure products. We turned to biocatalysis since it is a powerful and unique approach in the toolbox of organic chemists. ${ }^{24}$ Tryptophan synthase ${ }^{25}$ allows, in theory, simple access to a variety of enantiopure tryptophan derivatives from inexpensive serine and indole derivatives. ${ }^{26}$ After the expression and purification of the required enzyme, we applied this strategy to a series of 2-methylindole derivatives $\mathbf{8}(\mathrm{R}=\mathrm{H}$, OMe, F) and easily obtained the corresponding tryptophan analogs 9 (Scheme 3). The enzymatic crude mixtures were submitted to protein precipitation, filtered and lyophilized. Propargylation was then performed directly on the crude products, leading to fully propargylated intermediates. The gold-catalyzed cyclization in aqueous conditions then afforded the spiro derivatives $\mathbf{2} \mathbf{u}-\mathbf{w}$ in excellent global yields and diastereoselectivities over 3 steps. This strategy, implying just a final purification, proved to be very efficient to access densely functionalized enantiopure spiroindolenines. The enantiomeric excess measured on $2 \mathbf{u}$ by chiral HPLC (>99.5\%) showed that the whole sequence is totally stereoretentive. 
Scheme 3. Biocatalyzed Access to Enantioenriched Tryptophane Derivatives 9 and their in Situ Functionalizations/Spirocy-

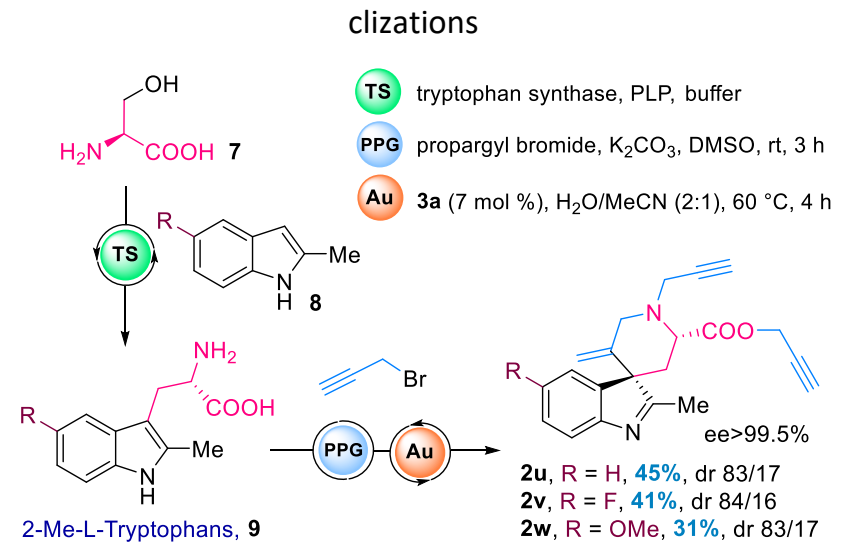

Finally, we studied the deprotection of the nosyl group of spiroindolenines to afford secondary amines that would be ready for further functionalization. Standard conditions using thiophenol and potassium carbonate on spiroindolenine $2 \mathrm{a}$ led to the isolation of the spiroamine 10 in $89 \%$ yield (Scheme 4). We wanted these conditions to be applicable in aqueous phase and for this purpose we developed a one-pot procedure combining the gold-catalyzed cyclization followed by the deprotection of the nosyl group via the addition of thiophenol and potassium carbonate. With this approach we obtained the amine $\mathbf{1 0}$ in $75 \%$ yield starting from the tryptamine $\mathbf{1 a}$.

Scheme 4. Deprotection of the Nosyl Group: a Tandem Cyclization/Deprotection Strategy to Access Unprotected Spiroindolenine

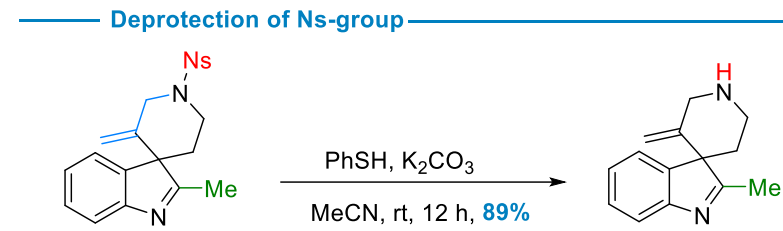

$2 a$

10

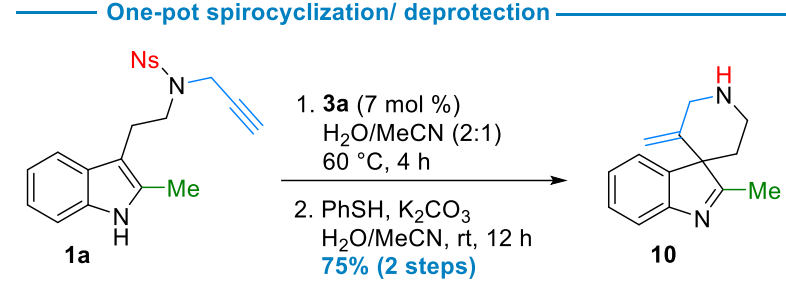

In summary, we have developed an efficient strategy to access spiroindolenines using gold-catalysis in aqueous conditions with high yields starting from tryptamine and tryptophan derivatives. Beyond the fact that operating with water as the main solvent answers partially to the general transitioning that organic synthesis has to do towards greener approaches, we showed here that water also has much to offer in terms of chemo- and regioselectivity. We were able, in particular, with these conditions access hitherto unattainable electron-poor spiroindolenines with high regioselectivities. The combination of biocatalysis and synthetic methods leading to enantiopure compounds in high efficiency also demonstrates that the introduction of biocatalysis to synthetic schemes is more relevant than ever. 


\section{Acknowledgements}

Nazarii Sabat thanks the CHARMMMAT Laboratory of Excellence (ANR-11-LABX0039) for financial support. This work was supported by European Research Council Consolidator Grant 617053 to O. Berteau.

\section{References}

(1) For general reviews on gold-catalysis, see: (a) Chiarucci, M.; Bandini, M. Beilstein J. Org. Chem. 2013, 9, 2586-2614. (b) Ranieri, B.; Escofet, I.; Echavarren, A. M. Org. Biomol. Chem. 2015, 13, 7103-7118. (c) Zi, W.; Toste, D. F. Chem. Soc. Rev. 2016, 45, 4567-4589.

(2) For general reviews on transition-metal dearomatization reactions, see: (a) Pape, A. R.; Kaliappan, K. P.; Kündig, E. P. Chem. Rev. 2000, 100, 2917-2940. (b) Zhuo, C.-X.; Zhang, W.; You, S.-L. Angew. Chem. Int. Ed. 2012, 51, 12662-12686.

(3) For reviews on indole spirocyclizations, see: (a) Roche, S. P.; Youte Tendoung, J.-J.; Tréguier, B. Tetrahedron 2015, 71, 3549-3591. (b) James, M. J.; O'Brien, P.; Taylor, R. J. K.; Unsworth, W. P. Chem. Eur. J. 2016, 22, 2856-2881. (c) Bariwal, J.; Voskressensky, L. G.; Van der Eycken, E. V. Chem. Soc. Rev. 2018, 47, 3831-3848.

(4) (a) Lovering, F.; Bikker, J.; Humblet, C. J. Med. Chem. 2009, 52, 6752-6756. (b) Lovering, F. MedChemComm 2013, 4, 515519.

(5) For reviews on gold-catalysis involving alkynes, see: (a) Bandini, M. Chem. Soc. Rev. 2011, 40, 1358-1367. (b) Ohno, H. Isr. J. Chem. 2013, 53, 869-882. (c) Dorel, R.; Echavarren, A. M. Chem. Rev. 2015, 115, 9028-9072.

(6) Selected recent examples using various catalysts, see: (a) James, M. J.; Cuthbertson, J. D.; O'Brien, P.; Taylor, R. J. K.; Unsworth, W. P. Angew. Chem. Int. Ed. 2015, 54, 7640-7643. (b) Zhuo, C.-X.; Zhou, Y.; Cheng, Q.; Huang, L.; You, S.-L. Angew. Chem. Int. Ed. 2015, 54, 14146-14149. (c) Wang, Y.; Zheng, C.; You, S.-L. Angew. Chem. Int. Ed. 2017, 56, 15093-15097. (d) Fedoseev, P.; Coppola, G.; Ojeda, G. M.; Van der Eycken, E. V. Chem. Commun. 2018, 54, 3625-3628. (e) Grugel, C. P.; Breit, B. Org. Lett. 2019.

(7) (a) Ferrer, C.; Amijs, C. H. M.; Echavarren, A. M. Chem. Eur. J. 2007, 13, 1358-1373. (b) Jia, M.; Cera, G.; Perrotta, D.; Monari, M.; Bandini, M. Chem. Eur. J. 2014, 20, 9875-9878. (c) Magné, V.; Blanchard, F.; Marinetti, A.; Voituriez, A.; Guinchard, X. Adv. Synth. Catal. 2016, 358, 3355 - 3361. (d) Magné, V.; Retailleau, P.; Marinetti, A.; Voituriez, A.; Guinchard, X. Molbank 2018, M985. (e) Glinsky-Olivier, N.; Retailleau, P.; Guinchard, X. Eur. J. Org. Chem. 2018, 5823. (f) Xu, W.; Wang, W.; Wang, X. Angew. Chem. Int. Ed. 2015, 54, 9546-9549. (g) Zhang, L.; Wang, Y.; Yao, Z.-J.; Wang, S.; Yu, Z.-X. J. Am. Chem. Soc. 2015, 137, 13290-13300. (g) Ferrer, C.; Echavarren, A. M. Angew. Chem. Int. Ed. 2006, 45, 1105-1109.

(8) (a) Lu, Y.; Du, X.; Jia, X.; Liu, Y. Adv. Synth. Catal. 2009, 351, 1517-1522. (b) Hashmi, A. S. K.; Yang, W.; Rominger, F. Adv. Synth. Catal. 2012, 354, 1273-1279.

(9) In a more general context, intramolecular cyclizations of indoles on electrophiles delivering 2-substituted products are often argued to evolve via spiroindolenines by C3 to C2 migrations. See, for example: (a) Zhuo, C.-X.; Wu, Q.-F.; Zhao, Q.; Xu, Q.-L.; You, S.-L. J. Am. Chem. Soc. 2013, 135, 8169-8172. (b) Loh, C. C. J.; Raabe, G.; Enders, D. Chem. Eur. J. 2012, 18, 1325013254.

(10) Selected recent examples, see: (a) Cera, G.; Chiarucci, M.; Mazzanti, A.; Mancinelli, M.; Bandini, M. Org. Lett. 2012, 14, 1350-1353. (b) Modha, S. G.; Kumar, A.; Vachhani, D. D.; Jacobs, J.; Sharma, S. K.; Parmar, V. S.; Van Meervelt, L.; Van der Eycken, E. V. Angew. Chem. Int. Ed. 2012, 51, 9572-9575. (c) Kumar, A.; Vachhani, D. D.; Modha, S. G.; Sharma, S. K.; Parmar, V. S.; Van der Eycken, E. V. Beilstein J. Org. Chem. 2013, 9, 2097-2102. (d) Podoll, J. D.; Liu, Y.; Chang, L.; Walls, S.; Wang, W.; Wang, X. Proc. Natl. Acad. Sci. 2013, 110, 15573-15578. (e) Wu, W.-T.; Ding, L.; Zhang, L.; You, S.-L. Org. Lett. 2020, 22, 12331238.

(11) (a) Liddon, J. T. R.; Rossi-Ashton, J. A.; Clarke, A. K.; Lynam, J. M.; Taylor, R. J. K.; Unsworth, W. P. Synthesis 2018, 50, 4829-4836. (b) Magné, V.; Marinetti, A.; Gandon, V.; Voituriez, A.; Guinchard, X. Adv. Synth. Catal. $2017,359,4036-4042$.

(12) Interestingly, Van der Eycken reported that tryptamines 2-propynoic amides lead to mixtures of compounds $\mathbf{B}$ and $\mathbf{C}$ in moderate yields. See ref 10c.

(13) (a) Blackmond, D. G.; Armstrong, A.; Coombe, V.; Wells, A. Angew. Chem. Int. Ed. 2007, 46, 3798-3800. (b) Grela, K.; Gułajski, Ł.; Skowerski, K., Metal-Catalyzed Reactions in Water. 2013; p 291. (c) Kitanosono, T.; Masuda, K.; Xu, P.; Kobayashi, S. Chem. Rev. 2018, 118, 679-746.

(14) Selected examples: (a) Winter, C.; Krause, N. Green Chem. 2009, 11, 1309-1312. (b) Minkler, S. R. K.; Lipshutz, B. H.; Krause, N. Angew. Chem. Int. Ed. 2011, 50, 7820-7823.

(15) Lipshutz, B. H.; Ghorai, S.; Abela, A. R.; Moser, R.; Nishikata, T.; Duplais, C.; Krasovskiy, A.; Gaston, R. D.; Gadwood, R. C. J. Org. Chem. 2011, 76, 4379.

(16) Additionally, we reacted $\mathbf{2} \mathbf{b}$ with TFA or catalyst $\mathbf{3 a}$. In both cases $\mathbf{2} \mathbf{b}$ remained unchanged, ensuring that compound $\mathbf{8 b}$ is not the result of a $\mathbf{1 , 2}$-shift from spiroindolenine $\mathbf{2} \mathbf{b}$, as it is well known in the Pictet-Spengler reactions. See for recent 
papers: (a) Zheng, C.; Xia, Z.-L.; You, S.-L. Chem 2018, 4, 1952-1966. (b) Gobé, V.; Gandon, V.; Guinchard, X. Adv. Synth. Catal. 2018, 360, 1280-1288. c) Glinsky-Olivier, N.; Yang, S.; Retailleau, P.; Gandon, V.; Guinchard, X. Org. Lett. 2019, $21,9446-9451$.

(17) Barrio, P.; Kumar, M.; Lu, Z.; Han, J.; Xu, B.; Hammond, G. B. Chem. Eur. J. 2016, 22, 16410-16414.

(18) As a side observation, we also noted that the reaction performed with $\mathrm{Me}{ }_{2} \mathrm{SAuCl}$ in $\mathrm{MeCN}$ affords exclusively the 8membered ring product $\mathbf{9 b}$, while operation in a $\mathrm{H}_{2} \mathrm{O}: \mathrm{MeCN}$ mixture (2:1) leads mainly to the 7-membered ring $\mathbf{8 b}(\mathbf{8 b}: \mathbf{9 b}$ ratio: $2 / 1$ ). In both cases, no trace of the spiro compound $\mathbf{2 b}$ was observed. See the Supporting Information.

(19) Mizushima, E.; Sato, K.; Hayashi, T.; Tanaka, M. Angew. Chem. Int. Ed. 2002, 41, 4563-4565.

(20) For other papers reporting similar strategies, see: (a) Miyake, F. Y.; Yakushijin, K.; Horne, D. A. Org. Lett. 2004, 6, 711713. (b) Liddon, J. T. R.; Clarke, A. K.; Taylor, R. J. K.; Unsworth, W. P. Org. Lett. 2016, 18, 6328-6331.

(21) See the Supporting Information for all details regarding the synthesis of the tryptophan starting materials.

(22) The relative and absolute stereochemistries of the main diastereoi-somers were easily determined to be $S, S$ from NOESY experiments, showing an interaction between $\mathrm{H} 4$ of the indole ring and the $\mathrm{H}$ adjacent to the ester group. See the Supporting Information.

(23) (a) Robinson, R.; Suginome, H. J. Chem. Soc. 1932, 298-304. (b) Hoshino, T. Justus Liebigs Ann. Chem. 1933, 500, 35-42.

(24) (a) Hailes, H. C.; Dalby, P. A.; Woodley, J. M. J. Chem. Technol. Biotechnol. 2007, 82, 1063-1066. (b) Sheldon, R. A.; Woodley, J. M. Chem. Rev. 2018, 118, 801-838.

(25) Caulkins, B. G.; Young, R. P.; Kudla, R. A.; Yang, C.; Bittbauer, T. J.; Bastin, B.; Hilario, E.; Fan, L.; Marsella, M. J.; Dunn, M. F.; Mueller, L. J. J. Am. Chem. Soc. 2016, 138, 15214-15226.

(26) (a) Goss, R. J. M.; Newill, P. L. A. Chem. Commun. 2006, 4924-4925. (b) Blei, F.; Baldeweg, F.; Fricke, J.; Hoffmeister, D. Chem. Eur. J. 2018, 24, 10028-10031. 